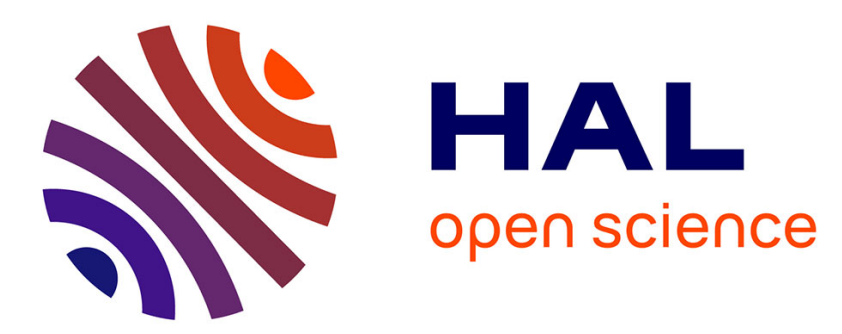

\title{
Amorphous Calcium Carbonate Based-Microparticles for Peptide Pulmonary Delivery
}

Frédéric Tewes, Oliviero L Gobbo, Carsten Ehrhardt, Anne Marie Healy

\section{To cite this version:}

Frédéric Tewes, Oliviero L Gobbo, Carsten Ehrhardt, Anne Marie Healy. Amorphous Calcium Carbonate Based-Microparticles for Peptide Pulmonary Delivery. ACS Applied Materials \& Interfaces, 2015, 2016, 8 (2), pp.1164-1175. 10.1021/acsami.5b09023 . hal-02484982

\section{HAL Id: hal-02484982 \\ https://hal.science/hal-02484982}

Submitted on 25 Feb 2020

HAL is a multi-disciplinary open access archive for the deposit and dissemination of scientific research documents, whether they are published or not. The documents may come from teaching and research institutions in France or abroad, or from public or private research centers.
L'archive ouverte pluridisciplinaire HAL, est destinée au dépôt et à la diffusion de documents scientifiques de niveau recherche, publiés ou non, émanant des établissements d'enseignement et de recherche français ou étrangers, des laboratoires publics ou privés. 


\section{Amorphous calcium carbonate based-microparticles for peptide pulmonary delivery}

Frederic Tewes ${ }^{1,2 *}$, Oliviero L. Gobbo ${ }^{1}$, Carsten Ehrhardt ${ }^{1}$ and Anne Marie Healy ${ }^{1 *}$.

1: School of Pharmacy and Pharmaceutical Sciences, Trinity College Dublin, Dublin 2, Ireland

2: INSERM U 1070, Pôle Biologie-Santé, Université de Poitiers, Faculté de Médecine \& Pharmacie, 1 rue Georges Bonnet, 86022 Poitiers Cedex, France

E-mail: ftewes@univ-poitiers.fr; healyam@tcd.ie

Keywords: Amorphous calcium carbonate, composite microparticle, pulmonary inhalation, biomimetic process, peptide 


\begin{abstract}
Amorphous calcium carbonate (ACC) is known to interact with proteins, for example in biogenic ACC, to form stable amorphous phases. The control of amorphous:crystalline and inorganic:organic ratios in inhalable calcium carbonate microparticles may enable particle properties to be adapted to suit the requirements of dry powders for pulmonary delivery by oral inhalation. For example, an amorphous phase can immobilise and stabilise polypeptides in their native structure and amorphous and crystalline phases have different mechanical properties. Therefore, inhalable composite microparticles made of inorganic (i.e. calcium carbonate and calcium formate) and organic (i.e. hyaluronan (HA)) amorphous and crystalline phases were investigated for peptide and protein pulmonary aerosol delivery. The crystalline:amorphous ratio and polymorphic form of the inorganic component was altered by changing the microparticle drying rate and by changing the ammonium carbonate and HA initial concentration. The bioactivity of the model peptide, salmon calcitonin (sCT), coprocessed with alpha-1-antitrypsin (AAT), a model protein with peptidase inhibitor activity was maintained during processing and the microparticles had excellent aerodynamic properties, making them suitable for pulmonary aerosol delivery. The bioavailability of sCT after aerosol delivery as SCT and AAT-loaded composite microparticles to rats was 4-times higher than that of sCT solution.
\end{abstract}

\title{
Keywords
}

Amorphous calcium carbonate, composite microparticle, pulmonary inhalation, biomimetic process, peptide 


\section{Introduction}

For peptides, polypeptides and proteins the lung is an attractive route into the bloodstream, owing to the high and thin surface area of the alveolar epithelium and due to lower metabolic activity compared to the gastrointestinal tract. ${ }^{1-2}$ Peptide deposition within the lung can be controlled by the development of peptide-loaded microparticles with suitable aerodynamic properties that allow them reach the distal lungs, where the absorption capacity is higher. When developing a polypeptide formulation it is mandatory to prevent its degradation and unfolding. This protection can be provided by the presence of excipient(s) in an amorphous phase that immobilise and isolate peptide molecules in their native structure. ${ }^{3}$ Ideally, in this vitrification-based stabilisation strategy, both polypeptide and excipient(s) are amorphous and miscible, forming a single amorphous phase, which should have a high glass transition temperature $\left(T_{\mathrm{g}}\right)$ in order to be stable at room temperature. According to Gordon and Taylor ${ }^{4}$ the $T_{\mathrm{g}}$ of this composite glass will be intermediate to the $T_{\mathrm{g}}$ of the polypeptide and the excipient. Also, the $T_{\mathrm{g}}$ of the excipient should be high in order to increase the $T_{\mathrm{g}}$ of the composite glass. In addition to vitrification, peptide-excipient interactions are important for polypeptide stabilisation. ${ }^{5}$ These interactions should replace the hydrogen-bonds formed by water at the surface of polypeptide molecule, preserving their native structure. Consequently, the presence of excipients forming an amorphous phase with the polypeptide in the formulations can be very important to stabilise these molecules. $^{3}$

Amorphous calcium carbonate (ACC) is an amorphous mineral phase which is known to interact with proteins and peptides, for example in biogenic ACC, to form stable amorphous phases. ${ }^{6-9}$ No information about the $T_{\mathrm{g}}$ of ACC is found in the literature. An estimation of the $T_{\mathrm{g}}$ of dry materials can be made from the melting temperature of its crystalline phase since studies have shown that the $T_{\mathrm{g}}$ is around 0.7 -times the melting temperature. ${ }^{10-11}$ Vaterite, the more metastable crystalline calcium carbonate $\left(\mathrm{CaCO}_{3}\right)$ polymorph, converts to calcite upon heating at transition temperatures of 320 $460^{\circ} \mathrm{C}$, depending on the method of preparation. ${ }^{12-14}$ If we assume, as a minimum, that the $T_{\mathrm{g}}$ of ACC is 0.7-times the phase transition temperature of vaterite to calcite, the $T_{\mathrm{g}}$ of ACC would be around $224^{\circ} \mathrm{C}$, which is higher than the $T_{\mathrm{g}}$ of most excipients used to stabilise amorphous pharmaceutical solids. Therefore, having potentially a high $T_{\mathrm{g}}$ and being able to interact with proteins, we hypothesise 
that ACC could be used to stabilise peptides in the formulation of inhalable particles. Qi et al. ${ }^{15-16}$ similarly proposed ACC nanospheres for protein drug delivery.

Additionally, it has been shown that ACC can coexist with one of the $\mathrm{CaCO}_{3}$ crystalline forms to produce material with advantageous specific properties. ${ }^{6,}{ }^{17-20}$ Biominerals such as seashells, ${ }^{6,}, 17$ eggshells ${ }^{21}$ and bones ${ }^{18,22-23}$ are examples of hybrid materials composed of biopolymer and amorphous and crystalline minerals having high mechanical strength and light weight. Amorphous materials have the advantage of being isotropic and elastic, with no preferred growth directions so they can be more easily shaped. ${ }^{8,20,24}$ On the other hand, crystalline $\mathrm{CaCO}_{3}$ are less soluble but harder and more stable than their amorphous counterpart. ${ }^{19}$ The combination of the two phases, amorphous and crystalline, may offer some advantageous properties to an inhalable powder. For example, materials with different proportions of amorphous and various polymorph crystalline phases could lead to different aerodynamic properties as well as different solubilities and dissolution rates.

Complex $\mathrm{CaCO}_{3}$-based structures are created by invertebrates by using the highly soluble ACC and a biopolymer controlling the $\mathrm{CaCO}_{3}$ polymorphs conversion. ${ }^{17,}{ }^{25-30}$ One way for the biopolymer to influence the shape of the mineral is by chemical interaction. ${ }^{31}$ Hyaluronate (HA) polysaccharide could be used to facilitate the particle formation. In fact, negatively charged carboxylic groups from HA could be used to interact with $\mathrm{Ca}^{2+}$ and control the nucleation of $\mathrm{CaCO}_{3} \cdot{ }^{32}$ Furthermore, $\mathrm{HA}$ is a ubiquitous anionic polysaccharide that is part of the extracellular lung matrix and has already been investigated as an inhalable therapeutic agent for lung diseases. ${ }^{33-35}$ For example, inhaled HA prevents the side effects of hypertonic saline inhalation alone, which is used to treat bronchiolitis and patients with cystic fibrosis. ${ }^{34,36}$

We hypothesise that inhalable microparticles could be made of ACC, crystalline $\mathrm{CaCO}_{3}$ and biopolymer (HA), enabling their properties to be adapted in terms of aerodynamic characteristics, drug release profile, mechanical strength and protein stability. In particles of this type, the properties could be tuned by controlling the organic:inorganic materials ratio and by controlling the solid state nature of the inorganic components. Therefore, we investigated the possibility of pulmonary delivery of salmon calcitonin ( $\mathrm{SCT}$ ) and alpha-1-antitrypsin (AAT), chosen as a model polypeptide and model protein, respectively, by way of inhalable composite microparticles made of $\mathrm{HA}$ and $\mathrm{CaCO}_{3} \cdot{ }^{37}$ 


\section{Results}

The spray drying process developed produced spherical hollow particles (shells) with wall thickness around $80 \mathrm{~nm}$ (Figure 1). The properties of these particles were tuned by altering three parameters: the spray drying inlet temperature, the concentration of HA and the concentration of ammonium carbonate $\left(\left(\mathrm{NH}_{4}\right)_{2} \mathrm{CO}_{3}\right)$ in the spray dried feed solutions (Table $\left.\mathbf{1}\right)$.

Table 1: Composition and physical properties of $\mathrm{Ca} / \mathrm{HA}$ composite particles

\begin{tabular}{|c|c|c|c|c|c|c|c|c|}
\hline & \multicolumn{7}{|c|}{ Formulation parameters } & \multicolumn{4}{|c|}{ Results } \\
\hline Code & $\begin{array}{c}\mathrm{Ca}(\mathrm{OH})_{2} \\
\left(\mathrm{~g} \mathrm{~L}^{-1}\right)\end{array}$ & $\begin{array}{c}\mathrm{HA} \\
\left(\mathrm{g} \mathrm{L}^{-1}\right)\end{array}$ & $\begin{array}{c}\left(\mathrm{NH}_{4}\right)_{2} \mathrm{CO}_{3} \\
\left(\mathrm{~g} \mathrm{~L}^{-1}\right)\end{array}$ & $\begin{array}{c}\text { inlet/outlet } \\
\text { temp }\left({ }^{\circ} \mathrm{C}\right)\end{array}$ & $\mathrm{D}_{50}(\mu \mathrm{m})$ & $\begin{array}{c}\text { specific surface } \\
\text { area }\left(\mathrm{m}^{2} \mathrm{~g}^{-1}\right)\end{array}$ & $\begin{array}{c}\text { True density } \\
\left(\mathrm{g} \mathrm{cm}^{-3}\right)\end{array}$ & $\begin{array}{c}\text { Ca loading } \\
\% \text { (Assay) }\end{array}$ \\
\hline temp1 & 0.8 & 0.2 & 1.2 & $100 / 39$ & $4.65 \pm 0.5$ & $17.8 \pm 1.2$ & $1.25 \pm 0.02$ & $36.8 \pm 2.3$ \\
\hline temp2 & 0.8 & 0.2 & 1.2 & $110 / 44$ & $4.55 \pm 0.4$ & $16.5 \pm 0.8$ & $1.06 \pm 0.07$ & $38.7 \pm 2.6$ \\
\hline temp3 & 0.8 & 0.2 & 1.2 & $120 / 50$ & $4.74 \pm 0.3$ & $19.6 \pm 0.8$ & $1.37 \pm 0.01$ & $34.3 \pm 2.9$ \\
\hline temp4 & 0.8 & 0.2 & 1.2 & $140 / 68$ & $4.67 \pm 0.4$ & $19.3 \pm 0.6$ & $2.06 \pm 0.01$ & $37.3 \pm 3.2$ \\
\hline \hline Carb1 & 0.8 & 0.2 & 1.2 & $120 / 50$ & $4.55 \pm 0.4$ & $16.5 \pm 0.6$ & $1.06 \pm 0.07$ & $38.7 \pm 2.6$ \\
\hline Carb2 & 0.8 & 0.2 & 2.4 & $120 / 50$ & $5.48 \pm 0.7$ & $30.1 \pm 1.0$ & $1.74 \pm 0.03$ & $57.3 \pm 4.6$ \\
\hline Carb3 & 0.8 & 0.2 & 4.8 & $120 / 50$ & $7.07 \pm 0.5$ & $28.0 \pm 0.9$ & $1.49 \pm 0.06$ & $65.2 \pm 3.1$ \\
\hline Carb4 & 0.8 & 0.2 & 6 & $120 / 50$ & $5.34 \pm 0.3$ & $23.6 \pm 0.8$ & $2.26 \pm 0.06$ & $53.5 \pm 4.0$ \\
\hline \hline HA1 & 0.8 & 0.1 & 1.2 & $120 / 50$ & $5.36 \pm 0.4$ & $18.7 \pm 0.6$ & $2.35 \pm 0.05$ & $48.9 \pm 2.9$ \\
\hline HA2 & 0.8 & 0.2 & 1.2 & $120 / 50$ & $4.74 \pm 0.3$ & $19.6 \pm 0.8$ & $1.37 \pm 0.01$ & $34.3 \pm 2.9$ \\
\hline HA3 & 0.8 & 0.4 & 1.2 & $120 / 50$ & $7.45 \pm 0.5$ & $17.7 \pm 0.7$ & $1.10 \pm 0.05$ & $34.6 \pm 3.5$ \\
\hline HA4 & 0.8 & 0.6 & 1.2 & $120 / 50$ & $10.20 \pm 0.6$ & $15.7 \pm 0.8$ & $1.21 \pm 0.10$ & $32.0 \pm 4.1$ \\
\hline
\end{tabular}




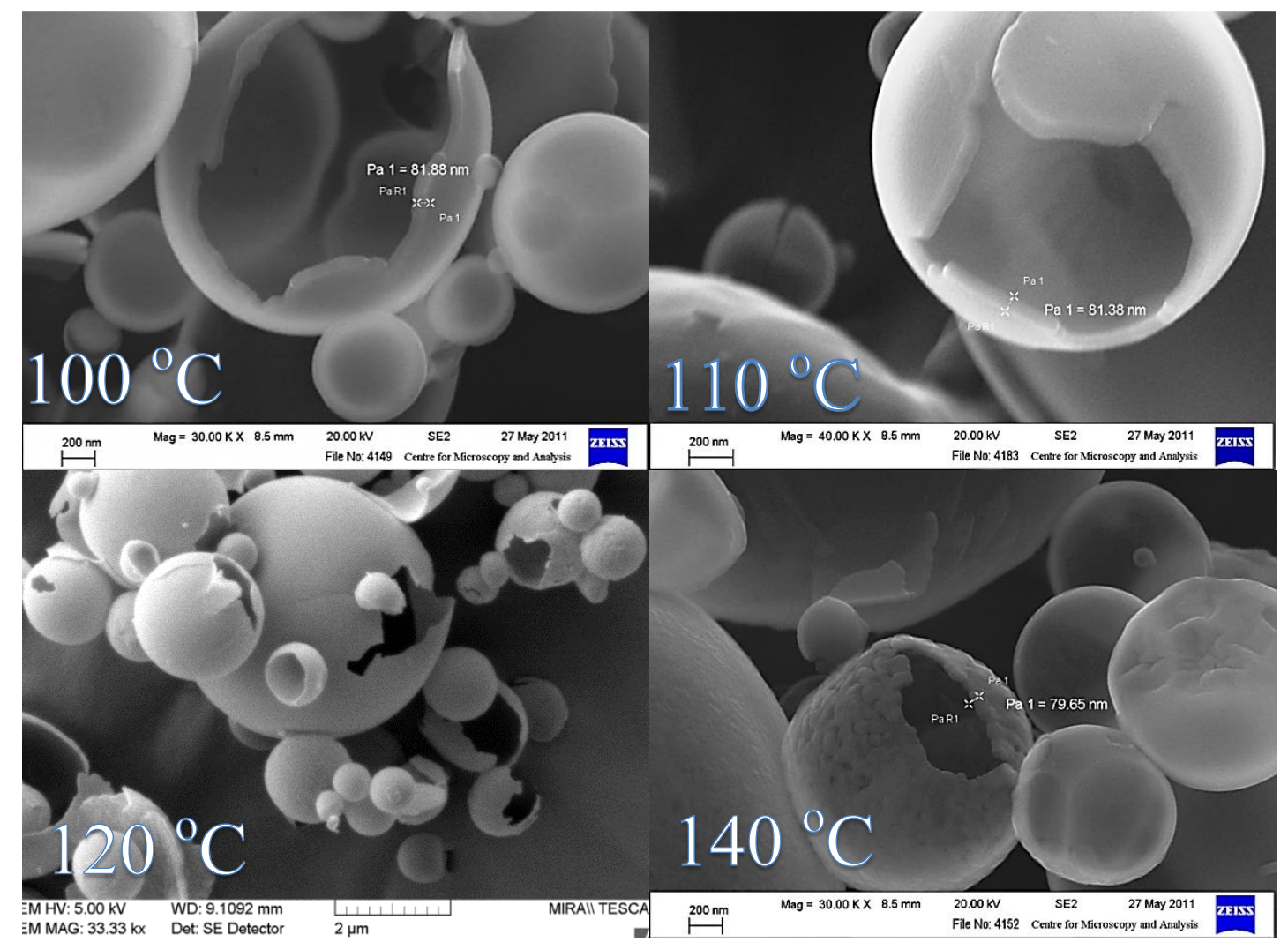

Figure 1: SEM micrographs of $\mathrm{Ca} / \mathrm{HA}$ composite microparticles formulated at different spray drying inlet temperatures $\left(\mathbf{T}_{\text {inlet }}\right)$.

\subsection{Processing temperature effect}

Changing the spray drying inlet temperature $\left(\mathrm{T}_{\text {inlet }}\right)$ in the $100{ }^{\circ} \mathrm{C}-140{ }^{\circ} \mathrm{C}$ range did not alter the particle morphology (Figure 1) or particle size distribution (Table 1). The formulations had a volume median geometric diameter $\left(D_{50}\right)$ around $4.6 \pm 0.4 \mu \mathrm{m}$ and high specific surface area values $(16.5$ to $19.6 \mathrm{~m}^{2} \mathrm{~g}^{-1}$ ). The calcium concentration in the particles was not modified but the true density of the particle changed with the $T_{\text {inlet }}$ (Table 1), indicating a change in their composition or in their solid state. The solid state of the powders was first analysed by XRD (Figure 2). Powders formulated at a $\mathrm{T}_{\text {inlet }}$ of $100{ }^{\circ} \mathrm{C}$ showed just a diffuse halo on their XRD pattern, characteristic of XRD amorphous material (Figure 2A). An increase in $\mathrm{T}_{\text {inlet }}$ from $110{ }^{\circ} \mathrm{C}$ up to $140{ }^{\circ} \mathrm{C}$ led to the appearance of low intensity diffraction peaks ascribed to crystalline calcium formate $\left(\mathrm{Ca}(\mathrm{HCOO})_{2}\right) .{ }^{38}$ The presence of $\mathrm{Ca}(\mathrm{HCOO})_{2}$ resulted from the reaction between calcium hydroxide $\mathrm{Ca}(\mathrm{OH})_{2}$ and formic acid $(\mathrm{HCOOH})$ initially present in the solutions. 

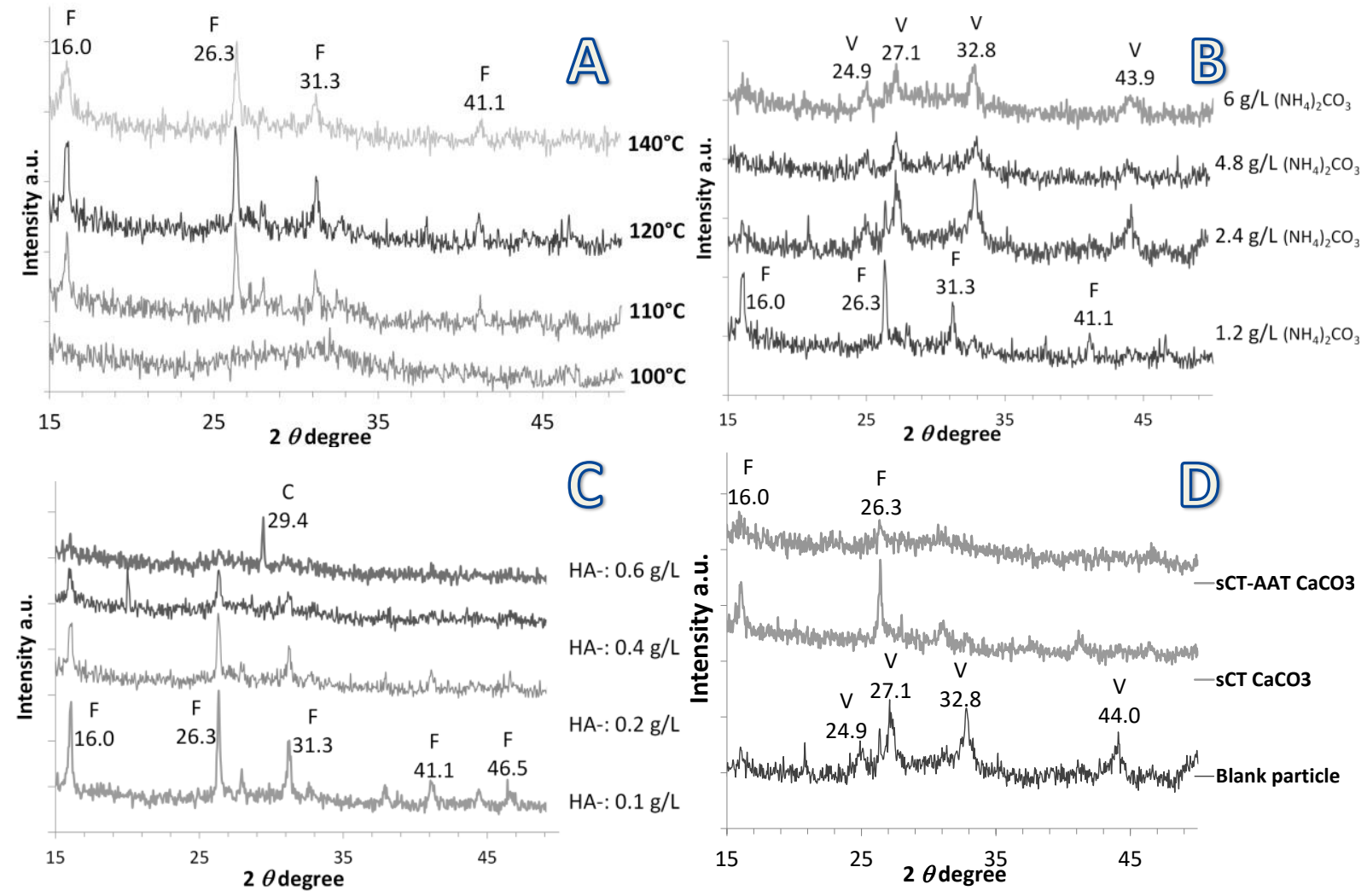

Figure 2: XRD patterns of $\mathrm{Ca} / \mathrm{HA}$ composite particle: A) Formulated at different temperatures, B) Formulated at different concentrations of $\left(\mathrm{NH}_{4}\right)_{2} \mathrm{CO}_{3}$, C) Formulated at different concentrations of HA, D) Loaded with SCT and AAT. (F) label is for calcium formate, (V) label is for vaterite $\mathrm{CaCO}_{3}$ polymorph and $(\mathrm{C})$ is for calcite $\mathrm{CaCO}_{3}$ polymorph.

Fourier transform-infrared (FTIR) spectroscopy was used to investigate the chemical nature of the particles (Figure 3A). All spectra presented absorption bands typical of carbonate and carboxylate. ${ }^{39-40}$ The absence of the carbonate absorption bands at 700,713 and at $745 \mathrm{~cm}^{-1} 40$ in the spectra indicates the absence of detectable anhydrous crystalline $\mathrm{CaCO}_{3}$ polymorphs. However, ACC spectra are characterised by a broad band of the carbonate bending at $866 \mathrm{~cm}^{-1}$ and a split in the asymmetric stretch of the carbonate ion at 1417 and $1488 \mathrm{~cm}^{-1} .9,19,31,41-43$ Carbonate absorption bands recorded for the microparticles formulated at $\mathrm{T}_{\text {inlet }}$ of $100{ }^{\circ} \mathrm{C}$ have maximal values typical for ACC, confirming the XRD data. 


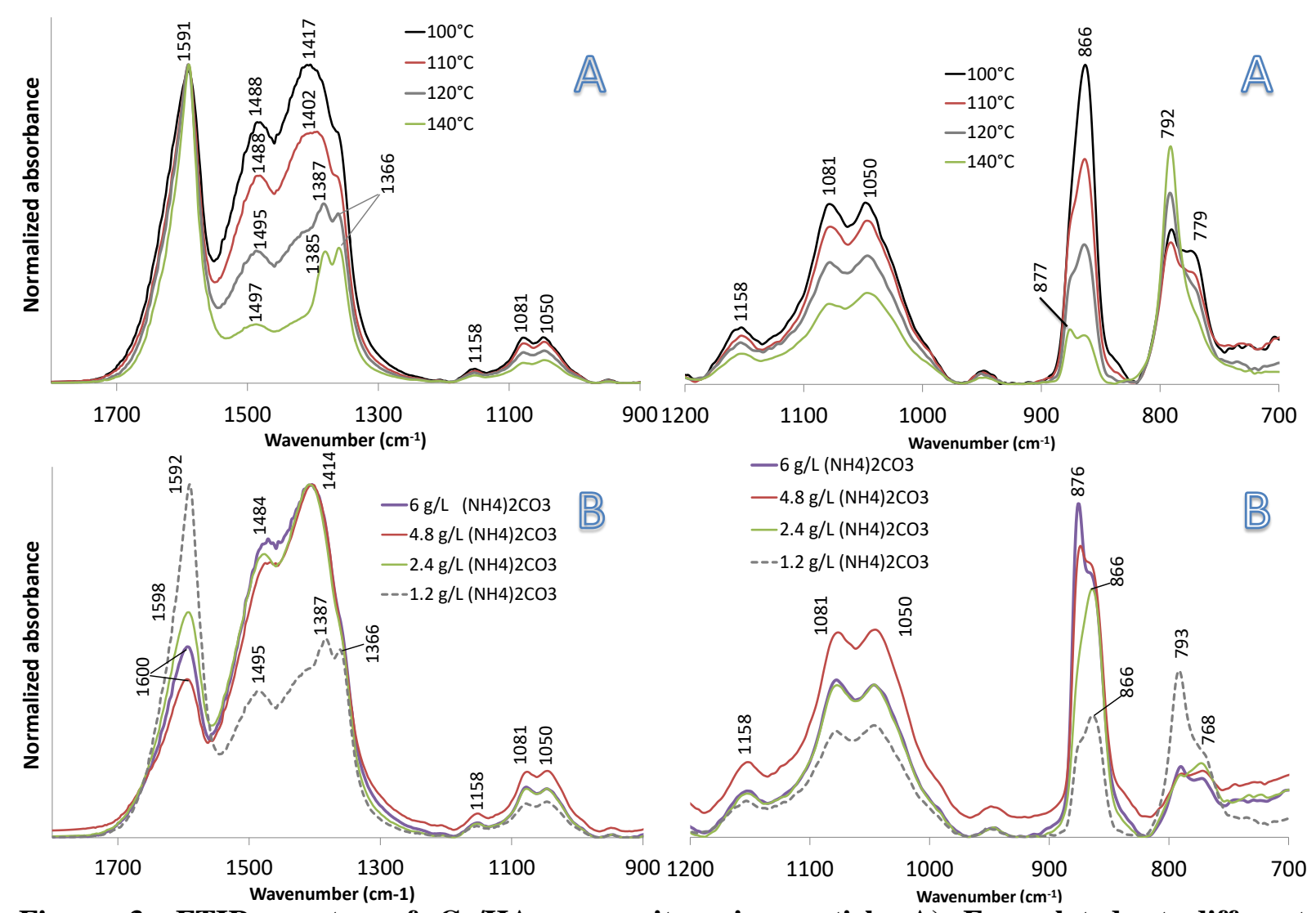

Figure 3: FTIR spectra of $\mathrm{Ca} / \mathrm{HA}$ composite microparticle A) Formulated at different temperatures, B) Formulated at different concentrations of $\left(\mathrm{NH}_{4}\right)_{2} \mathrm{CO}_{3}$.

An increase in $T_{\text {inlet }}$ resulted in a reduction in the intensity of bands typical of ACC. When processed at $\mathrm{T}_{\text {inlet }}=140{ }^{\circ} \mathrm{C}$, the $866 \mathrm{~cm}^{-1}$ band was split, with a sharper peak at $877 \mathrm{~cm}^{-1}$ indicative of the possible presence of some crystalline calcite or vaterite in addition to the ACC. ${ }^{42}$ The bands at $1591 \mathrm{~cm}^{-1}$ and $792 \mathrm{~cm}^{-1}$ can be attributed to the asymmetric stretch and the bending of the carboxyl group of calcium formate. ${ }^{39,44-45}$ The relative intensity of these bands increased with an increase in $T_{\text {inlet, }}$ suggesting an increase in calcium formate concentration in the particles.
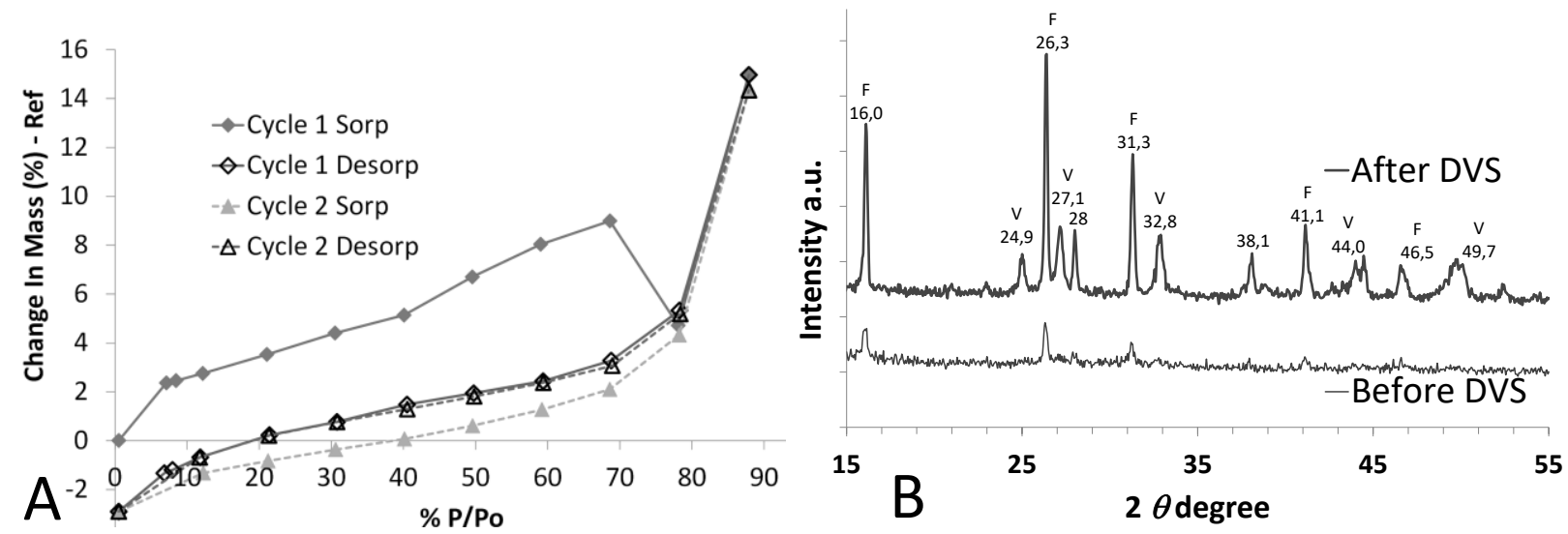

Figure 4: A) Water sorption isotherm $\left(25^{\circ} \mathrm{C}\right)$ of $\mathrm{Ca} / \mathrm{HA}$ composite microparticles formulated at $120{ }^{\circ} \mathrm{C}$ (temp2). B) XRD patterns recorded before and after DVS experiment. (F) label is for calcium formate and (V) label is for vaterite $\mathrm{CaCO}_{3}$ polymorph. 
For amorphous solids, the interactions with water are fundamental aspects to be studied because they can affect both dissolution properties and physical stability. ${ }^{46}$ The water sorption-desorption isotherm of composite microparticles formulated at $120{ }^{\circ} \mathrm{C}$ (temp2) showed water mass increase of $10 \%(\mathrm{w} / \mathrm{w})$ with an increase in RH up to $70 \%$, followed by a mass decrease for the 70 to $80 \%$ RH step (Figure 4A). A decrease in mass with increasing $\mathrm{RH}$ for amorphous substances corresponds to crystallisation of the material. ${ }^{47-49}$ XRD diffractograms of the formulation temp2 measured after the DVS experiment

(Figure 4B) showed new diffraction peaks characteristic of the vaterite $\mathrm{CaCO}_{3}$ polymorph ${ }^{50-51}$ and an increase in the intensity of the peak corresponding to calcium formate. Therefore, the crystallisation which occurred during water sorption corresponds to further crystallisation of calcium formate and to the crystallisation of the ACC to vaterite. The second water sorption-desorption cycle did not show any sign of crystallisation or polymorphic change.

\subsection{Ammonium carbonate concentration effect}

Changing $\left(\mathrm{NH}_{4}\right)_{2} \mathrm{CO}_{3}$ feed solution concentration did not alter particle morphology as observed by SEM (supporting information Figure S4), but changed their physicochemical properties (Table 1). The increase in $\left(\mathrm{NH}_{4}\right)_{2} \mathrm{CO}_{3}$ from $1.2 \mathrm{~g} \mathrm{~L}^{-1}$ to $4.8 \mathrm{~g} \mathrm{~L}^{-1}$ increased 2-fold the specific surface area and increased the calcium concentration in the particles from $38.7 \pm 2.6 \%$ to $65.2 \pm 3.1 \%$, respectively. True density changed variably with the $\left(\mathrm{NH}_{4}\right)_{2} \mathrm{CO}_{3}$ concentration but increased markedly to $2.26 \pm$ $0.06 \mathrm{~g} \mathrm{~cm}^{-3}$ for $6 \mathrm{~g} \mathrm{~L}^{-1}$ of $\left(\mathrm{NH}_{4}\right)_{2} \mathrm{CO}_{3}$. This density is higher than that of calcium formate $\left(2.009 \mathrm{~g} \mathrm{~cm}^{-}\right.$ ${ }^{3}$ ), and closer to the density of pure $\mathrm{CaCO}_{3}$ (vaterite $2.645 \mathrm{~g} \mathrm{~cm}^{-3}$, calcite $2.711 \mathrm{~g} \mathrm{~cm}^{-3}$ ). ${ }^{52}$ Analysis of the effect of $\left(\mathrm{NH}_{4}\right)_{2} \mathrm{CO}_{3}$ concentration on the particles properties by XRD (Figure 2B) and ATR-FTIR (Figure 3B) showed solid state changes. For a concentration of $1.2 \mathrm{~g} \mathrm{~L}^{-1}$ in $\left(\mathrm{NH}_{4}\right)_{2} \mathrm{CO}_{3}$ only the XRD Bragg peaks specific to calcium formate were observed. An increase in $\left(\mathrm{NH}_{4}\right)_{2} \mathrm{CO}_{3}$ concentration in the solutions higher than $1.2 \mathrm{~g} \mathrm{~L}^{-1}$ induced the formation of vaterite (Figure 3B). From $2.4 \mathrm{~g} \mathrm{~L}^{-1}$ to $6 \mathrm{~g} \mathrm{~L}^{-1}$ only Bragg peaks characteristic of vaterite were observed.

FTIR spectra of particles formulated at low $\left(\mathrm{NH}_{4}\right)_{2} \mathrm{CO}_{3}$ concentration (Figure 3B) were characterised by a broad band of the carbonate bending at $866 \mathrm{~cm}^{-1}$, typical of ACC. ${ }^{42}$ An increase in $\left(\mathrm{NH}_{4}\right)_{2} \mathrm{CO}_{3}$ concentration in the spray dried feed solution higher than $1.2 \mathrm{~g} \mathrm{~L}^{-1}$ induced a shift of this band to 876 $\mathrm{cm}^{-1}$, characteristic of calcite or vaterite. ${ }^{51}$ The bands split at 1414 and $1484 \mathrm{~cm}^{-1}$, which is 
characteristic of the asymmetric stretch of the carbonate ion ${ }^{9,19,41-42}$, increased with the $\left(\mathrm{NH}_{4}\right)_{2} \mathrm{CO}_{3}$ concentration increase, while the asymmetric stretch at $1592 \mathrm{~cm}^{-1}$ and the bending at $793 \mathrm{~cm}^{-1}$ of the carboxyl ion as calcium formate ${ }^{39}$ decreased in intensity, confirming the decrease in calcium formate concentration in the particles suggested by XRD.

\subsection{Hyaluronan concentration effect}

The major change induced by the increase in HA concentration was an increase in particle size, for HA concentrations higher than $0.2 \mathrm{~g} \mathrm{~L}^{-1}$, and a decrease in particle density and calcium concentration (Table 1). The increase in particle size could be attributed to the increase in the feed solution viscosity, producing larger droplets in the spray dryer. Particle morphology observed by SEM was similar for the various HA concentrations (Supporting Information Figure S5).

The intensities of the diffraction peaks on the XRD patterns were low, suggesting that the formulations were mostly amorphous (Figure 2C). However, an increase in HA concentration from $0.1 \mathrm{~g} \mathrm{~L}^{-1}$ to $0.6 \mathrm{~g}$ $\mathrm{L}^{-1}$ changed the solid state nature of the material. For HA concentrations ranging from $0.1 \mathrm{~g} \mathrm{~L}^{-1}$ to 0.4 $\mathrm{g} \mathrm{L}^{-1}$ only diffraction peaks characteristic of calcium formate were observed. The intensity of these peaks decreased with an increase in HA concentration, suggesting a decrease in concentration or in crystallinity of calcium formate in the particles. At a HA concentration of $0.6 \mathrm{~g} \mathrm{~L}^{-1}$, a diffraction peak at $29.4(2 \theta)$, specific to the $\mathrm{CaCO}_{3}$ polymorph, calcite, was observed. ${ }^{50-51}$ The major change observed on FTIR spectra (Supporting Information Figure S2) induced by an increase in HA concentration was a decrease in intensity of the calcium formate carboxyl band at $793 \mathrm{~cm}^{-1}, 39$ suggesting that the increase in HA concentration inhibited the formation of calcium formate in the particles. ${ }^{53}$ 


\subsection{Salmon calcitonin-loaded microparticles}

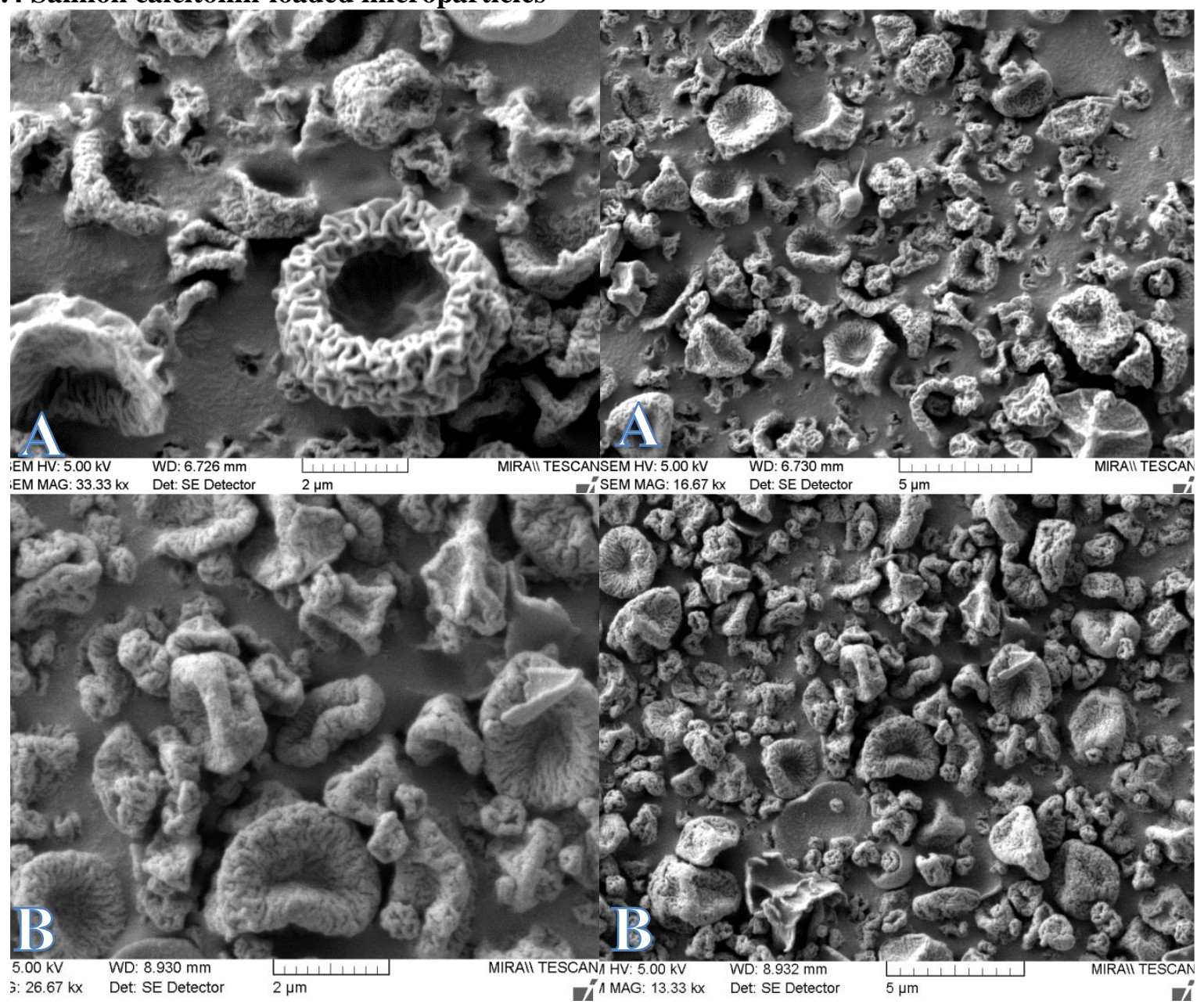

Figure 5: SEM micrographs of $\mathrm{Ca} / \mathrm{HA}$ composite particles loaded with $\mathrm{SCT}$ (A) and sCT and AAT (B).

In this study, sCT was chosen as a model peptide which is sensitive to pulmonary peptidase, limiting its pulmonary bioavailability (F\%). To achieve higher F\%, sCT was co-administrated with AAT to provide protection from lung peptidases. AAT is a 52-kDa protein produced by the liver, with its main physiological function being the inactivation of proteolytic enzymes in pulmonary tissue. Inhaled AAT has been shown to be suitable for the treatment of AAT deficiency and is currently in clinical trials. ${ }^{37}$ However, AAT has not yet been used to protect inhaled peptides against degradation and could be an interesting new approach.

sCT and sCT-AAT-loaded microparticles were formulated by adding SCT or SCT and AAT to the Carb2 formulation, which was principally composed of amorphous materials (Table 1). This formulation was chosen, not only because of its amorphous composition, but also based on the high specific surface area and low $\mathrm{D}_{50}$, suggesting good aerodynamic properties. The addition of sCT alone 
(loading $24.6 \pm 2.4 \%(\mathrm{w} / \mathrm{w})$ ) or AAT and $\mathrm{sCT}$ (loading $9.0 \pm 0.8 \%(\mathrm{w} / \mathrm{w} /)$ ) in the same proportion in the composite microparticles totally changed their morphology as observed by SEM (Figure 5). Blank particles were hollow shells, but became crimpled basket-shaped particles in the presence of sCT. This new morphology, with rough wrinkled surface should enhance the particle aerodynamic properties by increasing the particle shape factor. ${ }^{54}$

Again, all formulation XRD patterns had very low intensity diffraction peaks, revealing the low degree of crystallinity in the particles. The only residual diffraction peaks recorded for the blank particles indicated the presence of vaterite (Figure 2D). The sCT-loaded particles XRD pattern showed only low intensity peaks specific to calcium formate. The loading of both sCT and AAT made the formulations completely XRD amorphous. Analysis by FTIR showed that the incorporation of SCT in the formulation increased the intensity of the bands assigned to calcium formate and decreased the intensity of the band characteristic of ACC (Supporting Information Figure S2). The combined addition of sCT and AAT resulted in an increase in intensity of the FTIR band characteristic of ACC, which was consistent with the XRD results.

As was the case for the blank particles, the water sorption-desorption isotherm of sCT-AAT-loaded microparticles (supplementary information Figure S6) showed mass increase with an increase in RH up to $70 \%$, followed by a mass decrease for the 70 to $80 \%$ RH step. The XRD patterns of sCT and sCT-AAT-loaded formulations recorded after a full water sorption-desorption isotherm showed diffraction peaks specific to vaterite and calcium formate of higher intensity than before the $\mathrm{RH}$ change cycle. Thus, as for the blank particles, two crystallisation processes occurred at $80 \%$ of RH, the crystallisation of vaterite from ACC and the increase in crystalline calcium formate.

Aerodynamic analysis of the sCT-AAT-loaded microparticles showed optimal properties for lung inhalation when using a dry powder inhaler (Supporting information Figure S7). In order to reach the pulmonary alveoli, particles must have an aerodynamic diameter in the 1 to $5 \mu \mathrm{m}$ range. ${ }^{54} \mathrm{sCT}$-AATloaded particles emitted from the dry powder inhaler had a mass median aerodynamic diameter of 2.89 $\pm 0.23 \mu \mathrm{m}$ with a geometric standard deviation of $1.82 \pm 0.16$. The fine particle fraction, the fraction of particles that are capable of penetrating and depositing within the lungs, expressed as per the emitted recovered dose, was $64.1 \pm 7.1 \%$. 

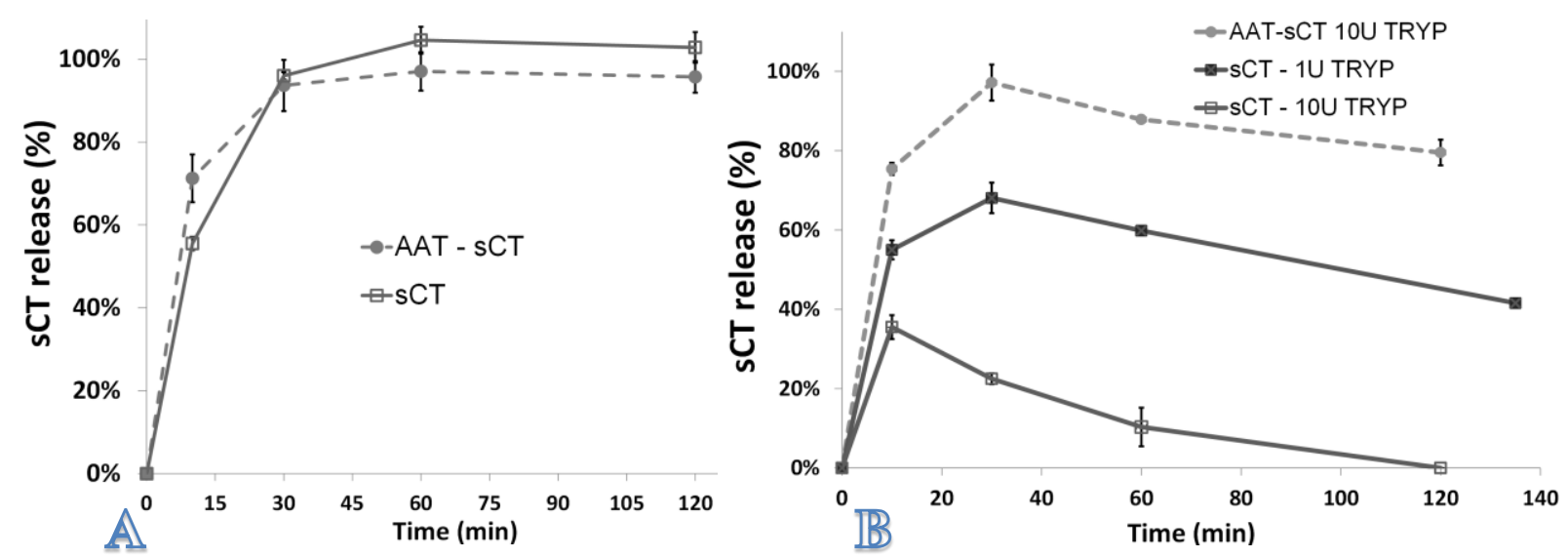

Figure 6: sCT release from sCT and SCT-AAT-loaded microparticles in the absence (A) or in the presence (B) of trypsin in the PBS pH 7.4.

sCT release from sCT or sCT-AAT-loaded microparticles was complete after 30 min in PBS pH 7.4

(Figure 6A). Both formulations showed the same fast release profile. In the presence of trypsin in the release buffer, sCT was rapidly degraded, leading to a reduction in intact sCT released from sCTloaded particles, with the rate of degradation increasing with the trypsin concentration (Figure 6B). In the presence of $10 \mathrm{U}$ (BAEE units) of trypsin in the buffer, all the sCT released from the sCT-loaded particles was degraded after $2 \mathrm{~h}$. For sCT release from sCT-AAT-loaded microparticles, higher proteolytic stability was observed and $85 \%$ of the sCT initially loaded in the particles was detected in the buffer containing $10 \mathrm{U}$ of trypsin after $2 \mathrm{~h}$. These results suggest that AAT proteins present in the particles were still active and able to protect $\mathrm{SCT}$ from degradation.

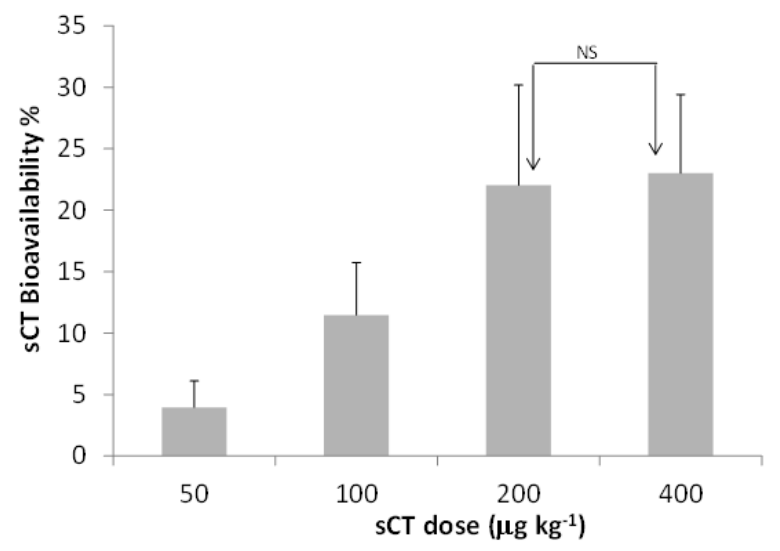

Figure 7: sCT bioavailability (F) after pulmonary administration of various sCT dose by nebulising $100 \mu \mathrm{L}$ of $\mathrm{sCT}$ solutions at different concentration.

sCT displayed nonlinear pulmonary pharmacokinetics (PK) in rat and increasing the sCT dose by nebulising sCT solutions of increasing concentration changed the sCT bioavailability (Figure 7). At a low dose $\left(50 \mu \mathrm{g} \mathrm{kg}^{-1}\right)$ pulmonary sCT bioavailability from a nebulised solution was low (4\%) and 
increased with increasing dose to plateau at around $23 \%$ for a dose of 200 and $400 \mu \mathrm{g} \mathrm{kg}^{-1}$. Also, increasing the sCT dose increased $\mathrm{T}_{\max }$ from $5 \mathrm{~min}$ for a dose of $50 \mu \mathrm{g} \mathrm{kg}^{-1}$ up to $15 \mathrm{~min}$ for a dose of $200 \mu \mathrm{g} \mathrm{kg}^{-1}$. The non-linear sCT PK following pulmonary administration was not due to a change in sCT plasma elimination, as i.v. SCT PK was linear in the same dose range (50 - $\left.400 \mu \mathrm{g} \mathrm{kg}^{-1}\right)$. Likewise, sCT demonstrated linear PK following i.v. administration of 1,5 and $10 \mu \mathrm{g}$ doses in rats. ${ }^{55}$ However, sCT PK after i.v. administration in dogs were non-linear over a higher dose range (1-1000 $\mu \mathrm{g}) .{ }^{55}$ Average $\mathrm{sCT}$ plasma concentration-versus-time profiles were different after pulmonary administration of a solution of sCT alone $\left(100 \mu \mathrm{g} \mathrm{kg}^{-1}\right)$ or when combined with AAT (Figure 8A). For sCT alone, sCT lung absorption was fast, with a $\mathrm{T}_{\max }$ of $4.2 \pm 1.1 \mathrm{~min}$, followed by a fast elimination leading to a bioavailability (F) of $11.9 \pm 3.9 \%$.
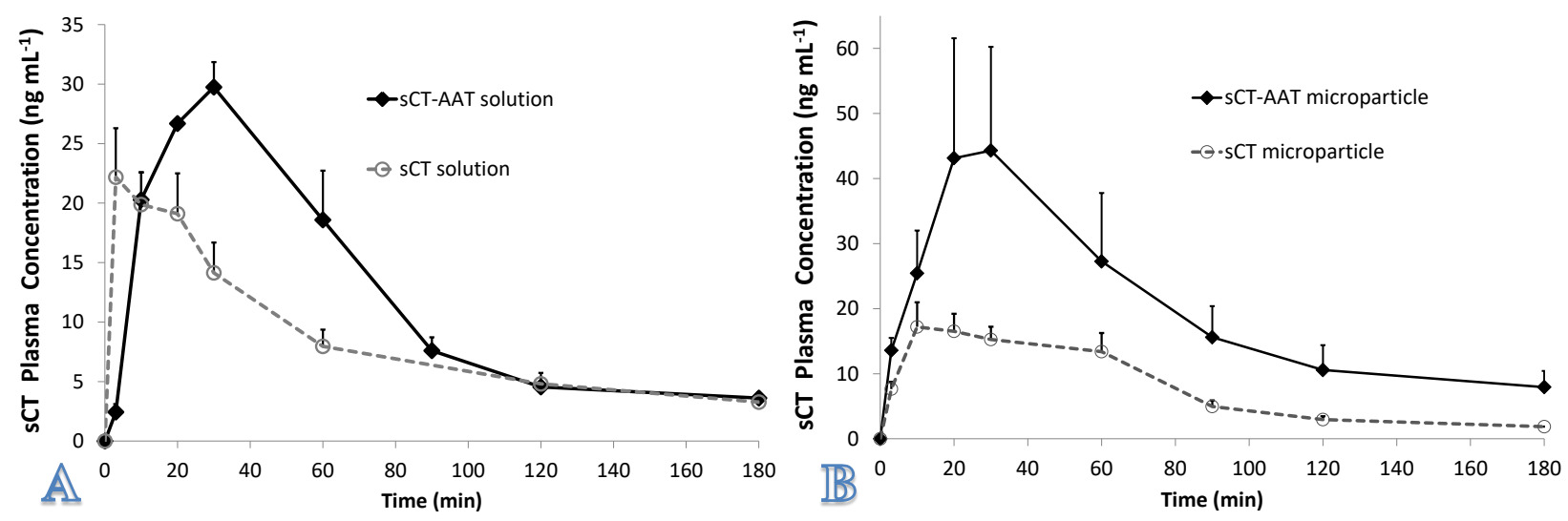

Figure 8: sCT plasma concentration-versus-time profiles after: A) sCT solution nebulisation B) sCT-loaded composite microparticles inhalation (mean \pm SD). Dose 100 $\mu \mathrm{g} \mathrm{Kg}$.

In the presence of AAT, sCT bioavailability was not significantly changed. However, $\mathrm{T}_{\max }$ was shifted to $30 \pm 0.1 \mathrm{~min}$ and the systemic absorption was slowed down in comparison to the pure sCT solution, as described by the lower absorption constant $\mathrm{K}_{\mathrm{a}}=0.128 \pm 0.002 \mathrm{~min}^{-1}$ (Table 2).

Administration of sCT as composite microparticles (without AAT) increased only the absorption $\mathrm{T}_{\max }$ but other all pharmacokinetic parameters were identical to those obtained with pure sCT solutions. This increase in $\mathrm{T}_{\max }$ should be related to the time for $\mathrm{sCT}$ release from the particles. With the addition of AAT to the particles, most of the pharmacokinetic parameters were significantly changed. $\mathrm{C}_{\max }$, $\mathrm{T}_{\max }$ and AUC of sCT plasma concentrations-versus-time profiles were increased, leading to a 4-times increased sCT bioavailability compared to sCT solution (Figure 8B). 
Table 2: Pharmacokinetic parameters of the sCT plasma concentration versus time profiles. (mean $\pm \mathrm{SD}(\mathrm{n}=\mathbf{2 - 7 )}) ; * \mathbf{P}<0.05$, indicating a significant difference between the mean values of the PK parameters compare to the one obtained for $\mathrm{SCT}$ solution pulmonary administration. AUC $\infty$ is the area under the sCT plasma concentration versus time curve. Tmax is the time of peak sCT plasma concentration. Cmax is the maximal sCT plasma concentration obtained at Tmax. ka is the first order absorption rate constant. F (the bioavailability) is the fraction of the dose which can be absorbed

\begin{tabular}{|ccccc|}
\hline & sCT solution & $\begin{array}{c}\text { sCT AAT } \\
\text { solution }\end{array}$ & $\begin{array}{c}\text { sCT } \\
\text { composite } \\
\text { microparticles }\end{array}$ & $\begin{array}{c}\text { sCT-AAT } \\
\text { composite } \\
\text { microparticles }\end{array}$ \\
\hline AUC $\infty\left(\min \mathrm{ng} \mathrm{mL}^{-1}\right)$ & $1493 \pm 526$ & $2319 \pm 397$ & $1705 \pm 549$ & $4907 \pm 3085^{\star}$ \\
Tmax $(\min )$ & $4.2 \pm 1.1$ & $30.0 \pm 0.1$ & $16.6 \pm 4.7$ & $23.3 \pm 4.7^{\star}$ \\
$\mathrm{Cmax}(\mathrm{ng} \mathrm{mL-1)}$ & $24.1 \pm 4.5$ & $31.4 \pm 1.3$ & $18.0 \pm 6.2$ & $46.8 \pm 30.3^{\star}$ \\
$\mathrm{K}_{\mathrm{a}}\left(\mathrm{min}^{-1}\right)$ & $0.476 \pm 0.152$ & $0.128 \pm 0.002^{\star}$ & $0.188 \pm 0.027^{\star}$ & $0.155 \pm 0.025^{\star}$ \\
$\mathrm{F}(\%)$ & $11.9 \pm 3.9$ & $18.5 \pm 3.2$ & $13.6 \pm 5.4$ & $39.2 \pm 24.6^{\star}$ \\
\hline
\end{tabular}




\section{Discussion}

In many living entities, solid $\mathrm{CaCO}_{3}$ is shaped into different structures to adapt and fulfil different functions. ${ }^{19}$ Eggshell and bones are examples of $\mathrm{CaCO} 3$-made structures which are light and have good mechanical resistance. In this study, we attempt to use these properties to formulate microparticles for pulmonary peptide delivery. We showed that shell-like inorganic-organic inhalable microparticles could be made of $\mathrm{CaCO}_{3}$, calcium formate and biopolymer (HA) with properties matching the pharmaceutical requirements of an aerosolisable powder. In this process, the microparticle properties were tuned by different means, i.e. by altering the drying temperature, the $\left(\mathrm{NH}_{4}\right)_{2} \mathrm{CO}_{3}$ and $\mathrm{HA}$ concentration in the spray dried feed solutions.

Increasing the spray drying temperature, which increases the rate and extent of drying ${ }^{56}$ had several effects on the particles properties. First, it favoured the formation of calcium formate $\left(\mathrm{Ca}(\mathrm{HCOO})_{2}\right)$ over the formation of $\mathrm{CaCO}_{3}$. Second, it impacted on the solid state of the particles' inorganic component. Calcium formate was present in the particles in the crystalline and/or amorphous state. To our knowledge, this is the first report of amorphous calcium formate. Spray drying is a process which often produces amorphous pharmaceuticals. The ratio between amorphous and crystalline calcium formate depended on the spray drying temperature. At low drying temperature $\left(100{ }^{\circ} \mathrm{C}\right)$ the particles were fully amorphous. An increase in temperature up to $140{ }^{\circ} \mathrm{C}$ led to the increased formation of crystalline calcium formate phase. $\mathrm{CaCO}_{3}$ was XRD amorphous at all processing temperatures used. However, for the particles produced at $140{ }^{\circ} \mathrm{C}$, FTIR experiments suggested the presence, in low proportions, of a calcium carbonate phase which was more organised than $\mathrm{ACC} . \mathrm{CaCO}_{3}$ can solidify as three anhydrous crystalline polymorphs (calcite, aragonite, vaterite), two hydrates (hexahydrate and monohydrate) and ACC, which is the most thermodynamically unstable. ${ }^{25}$ Stable ACC can be obtained by the addition of different excipients, such as polymers, to the solid phase ${ }^{6,28,57}$ and by controlling the amount of water present in the solid phase (hydrated ACC). This last phenomenon was mainly observed with ACC produced in living organisms. ${ }^{8}$ Water present in $\mathrm{CaCO}_{3}$ lowers the energy barrier towards the solidification of hydrated ACC compared with the anhydrous crystalline forms. ${ }^{43,58}$ Also, maintaining this hydration could be important for stability of the ACC, as crystallisation induced by heat is thought to involve dehydration of hydrated ACC..$^{30,43,52,59-62}$ Likewise, ACC crystallisation can 
be retarded by providing a barrier to water $\operatorname{loss} .{ }^{43}$ In a pharmaceutical context, water is usually considered to be a plasticizer, decreasing the $T_{\mathrm{g}}$ of an amorphous solid and increasing the local molecular mobility and physical instability. It is generally recognized that exposure to water has to be avoided in order to obtain stable amorphous pharmaceutical solids; thus the behaviour of ACC appears to be an exception.

At ambient temperature, as for the polymorphic transformation of crystalline $\mathrm{CaCO}_{3}$, $\mathrm{ACC}$ crystallisation is triggered through local superficial ACC dissolution in surface water and local crystallisation to form nucleation clusters. ${ }^{43}$ Surface water is thus important for this dissolutioncrystallisation process to occur. For example, ACC washed with ethanol to remove surface water or ACC prepared by freeze drying that has no surface water shows extended stability. ${ }^{63-64}$ The conversion of the ACC into the vaterite crystalline phase observed when the relative humidity was increased above $70 \%$ should be related to the local dissolution of ACC in adsorbed and absorbed water. Generally, polymorphs formed after ACC crystallization at low temperature (14 to $\left.30^{\circ} \mathrm{C}\right)$ are vaterite and calcite ${ }^{61}$ Recent work suggests that vaterite is often the first phase to form during crystallisation of pure ACC. ${ }^{59-60}$ However, it is not a general result and depends on how the ACC is made. ${ }^{65}$ Aqueous solubility of hydrates is generally lower than the anhydrous form. ${ }^{66}$ The dissolution-crystallisation process needed to crystallise $\mathrm{CaCO}_{3}$ could be favoured for anhydrous compared to hydrated ACC. Thus, avoiding the complete dehydration of $\mathrm{CaCO}_{3}$ during the solidification step, by adjusting the $\mathrm{T}_{\text {inlet, }}$ seems important to formulate stable ACC by spray drying. Controlling the spray drying temperature, water evaporation rate and residual amount of water in the final particle could be a way to form stable amorphous/crystalline composite particles. $\mathrm{CaCO}_{3}$ may not be exclusively involved in this crystallization process and this could happen for calcium formate also.

Changing $\mathrm{HA}$ and $\left(\mathrm{NH}_{4}\right)_{2} \mathrm{CO}_{3}$ concentrations had several consequences on the nature of the particles' inorganic component. First, increasing $\mathrm{HA}$ and $\left(\mathrm{NH}_{4}\right)_{2} \mathrm{CO}_{3}$ concentrations facilitated the formation of $\mathrm{CaCO}_{3}$ over calcium formate. Second, $\mathrm{HA}$ and $\left(\mathrm{NH}_{4}\right)_{2} \mathrm{CO}_{3}$ concentrations influenced the solid state nature of the $\mathrm{CaCO}_{3}$. High $\mathrm{HA}$ concentration induced the formation of calcite, the stable $\mathrm{CaCO}_{3}$ polymorph. Negatively charged carboxylic groups of HA polymers are assumed to be responsible for nucleation of this particular $\mathrm{CaCO}_{3}$ polymorph by interacting with calcium ions. ${ }^{67}$ In fact, $\mathrm{HA}$ was 
previously shown to facilitate and control the formation and shape of calcite. ${ }^{32}$ Also, it has been shown that $\mathrm{CaCO}_{3}$ polymorphic transformations proceeded by the dissolution of the metastable phases and the growth of calcite, and that the rate-determining step was the growth of calcite. ${ }^{62}$ An increase in HA concentration results in an increase in solution viscosity and slows down the mobility of the $\mathrm{Ca}^{2+}$ and $\mathrm{CO}_{3}^{2-}$ ions. This reduction of the ions' mobility should favor the thermodynamic over the kinetic control of the crystallisation process, leading to the formation of the stable calcite. In fact, an increasing proportion of calcite over vaterite was previously observed for $\mathrm{CaCO}_{3}$ growth in solution for solutions with viscosities above $1.6 \mathrm{mPa} \mathrm{s} .{ }^{68}$

Increasing $\left(\mathrm{NH}_{4}\right)_{2} \mathrm{CO}_{3}$ concentration facilitates the formation of vaterite phase. Changing $\left(\mathrm{NH}_{4}\right)_{2} \mathrm{CO}_{3}$ feed solution concentration had a direct effect on carbonate ion concentration. A previous study showed that the carbonate ion concentration had a kinetic control on the growth of $\mathrm{CaCO}_{3}$, facilitating the formation of vaterite as the carbonate ion concentration increased for a given calcium ion concentration. ${ }^{69}$

The control of the solid state nature and composition of the inorganic part of the particles could enable their physicochemical properties to be adapted to best suit the requirements of pharmaceutical dry powders for inhalation. This new process produced particles especially well-suited for pulmonary drug delivery. In order to reach the pulmonary alveoli, particles must have an aerodynamic-equivalent diameter $\left(d_{a}\right)$ in the $1-5 \mu \mathrm{m}$ range. ${ }^{54} d_{a}$ is linked to the volume-equivalent geometric diameter $\left(d_{g}\right)$ of the particles by the particle shape, evaluated by the particle shape factor $(\chi)$, and by the particle density. ${ }^{70-71} \chi$ is defined as the ratio of the drag force on a particle to the drag force on a volumeequivalent sphere at the same velocity. ${ }^{71}$ In order to decrease $d_{a}$ of geometrically large particles below $5 \mu \mathrm{m}$, several studies focused on enhancing the particle porosity and specific surface area to increase $\chi$ and decrease $\rho_{p} \cdot{ }^{48-49,72-74}$ All blank particles produced in the current study were shell-like and had high specific surface areas compared to solid spherical particles of the same size. ${ }^{74}$ The incorporation of $\mathrm{sCT}$ in the formulation completely changed the particle morphology to wrinkled particles. Particle morphology produced by spray drying can be explained by the material's Peclet number $(P e) .^{72}$ The Peclet number compares the diffusion rate of the solute and the evaporation rate of the receding droplet surface. For materials having a $P e$ larger than 1, e.g. moving slowly in the liquid, the sprayed 
droplet surface moves faster than the dissolved or suspended materials, resulting in their accumulation and solidification at the surface. The resulting particles can be hollow spheres if the shell becomes rigid quickly, as happened for the blank particles. If the surface is too soft, it can buckle or fold on the internal and external void space to form a wrinkled or dimpled morphology, as was observed for the particles containing sCT. sCT appears to make the particle wall softer, leading to the formation of wrinkled particles. In fact sCT has a $T_{\mathrm{g}}$ around $147^{\circ} \mathrm{C}^{75}$, which should be lower than the $T_{\mathrm{g}}$ of ACC and make the particle wall softer. Similarly, it was previously observed that the addition of sCT to spherical particles made of polyethylene glycol (PEG) and polyvinylpyrrolidone reduced the degree of crystallinity in the particles and made them wrinkled. ${ }^{49}$

The incorporation $\mathrm{SCT}$ and $\mathrm{AAT}$ in the formulation favoured the formation of $\mathrm{ACC}$ and resulted in the production of completely amorphous particles, that could be important to stabilize these molecules and prevent any structural damage during processing and storage. ${ }^{3}$ After landing in the lung, the microparticles release $\mathrm{sCT}$ that is then absorbed or eliminated from the lung by clearance mechanisms. sCT bioavailability may be improved by either increasing the $\mathrm{sCT}$ absorption rate or reducing the effect of clearance mechanisms. Depending on the region of the lung that the particle reaches, the lung clearance mechanisms are different. In the deep peripheral lung the main clearance mechanisms for sCT are proteases activity ${ }^{76}$ and macrophage phagocytosis. The release of sCT from the particles was fast and complete within $30 \mathrm{~min}$. ACC is the most soluble form of $\mathrm{CaCO}_{3}$ and dissolves quickly, which should be responsible for the fast sCT release. This fast release is beneficial, as it can prevent sCT macrophage degradation after particle phagocytosis and allows for a high sCT concentration gradient across the lung-blood barrier, facilitating sCT absorption.

sCT displayed non-linear pulmonary PK, leading to an increase in SCT bioavailability with an increase in sCT dose. This non-linear PK obtained after pulmonary nebulisation of sCT solution could involve the saturation of sCT clearance mechanisms. In fact, if above a certain sCT concentration, the elimination rate tends to reach a maximal value and there is no further increase in the elimination rate when $\mathrm{SCT}$ concentration increases, then an increase in $\mathrm{SCT}$ concentration in the lung must increase its bioavailability. However, from a sCT dose of $200 \mu \mathrm{g} \mathrm{kg}^{-1}$ and above, $\mathrm{sCT}$ bioavailability plateaued at around $23 \%$ and $\mathrm{T}_{\max }$ increased with the sCT dose, suggesting the slow-down of the sCT absorption 
and the action of other slower clearance mechanisms, resulting in a bioavailability of $100 \%$ not being achieved. Likewise, the increase in $\mathrm{T}_{\max }$ and the limitation of sCT bioavailability to $18.5 \pm 3.2 \%$ in the presence of AAT, after nebulisation of $\mathrm{SCT}$ and AAT solutions, could be explained by the saturation of sCT absorption mechanisms and the action of clearance mechanisms other than proteases.

Thus, AAT nebulised solution in the lung increased sCT bioavailability by reducing sCT enzymatic degradation. However, sCT bioavailability is limited by its absorption rate drop at high concentration. In the same way, pulmonary delivered PEGylated sCT had 4-times increased bioavailability due to higher proteolytic resistances and partly due to reduction of elimination rate in plasma, but reached only $50 \%$ bioavailability. ${ }^{77}$ This limitation could also be due to a slowing down of the sCT absorption rate with increasing $\mathrm{SCT}$ concentration in the lung and the concomitant action of other elimination mechanisms. sCT administered as sCT-AAT particles had higher bioavailability than $\mathrm{sCT}$ delivered as solution with or without AAT but had a similar absorption rate. This suggests that the AAT-loaded composite particles were able to further extend the protecting action of AAT in the lung to clearance mechanisms other than protease.

\section{Conclusions}

We have succeeded in developing a novel formulation approach to prepare shell-like composite microparticles made of selected polymorphs of calcium carbonate (amorphous, calcite and vaterite), calcium formate and hyaluronan. In this new process, different levels of control could be tuned to adapt the microparticle properties. The first level is the organic biopolymer/mineral $\left(\mathrm{CaCO}_{3}\right.$ and $\left.\mathrm{Ca}(\mathrm{HCOO})_{2}\right)$ ratio. The second level of control is the solid nature of the mineral component, crystalline/amorphous ratio and polymorphic properties. These inorganic/organic hybrid microparticles were able to preserve peptide and protein activities and deliver them to the lung. The combination of alpha-1-antitrypsin associated with composite particles was able to improve sCT bioavailability 4-fold. 


\section{Acknowledgements}

This publication has emanated from research conducted with the financial support of Science Foundation Ireland (SFI) under Grant Numbers 07/SRC/B1158 and SFI/12/RC/2275

\section{References}

1. Patton, J., Breathing life into protein drugs. Nature Biotechnology 1998, 16 (2), 141143.

2. Patton, J. S.; Byron, P. R., Inhaling medicines: delivering drugs to the body through the lungs. Nature Reviews Drug Discovery 2007, 6 (1), 67-74.

3. Yu, L., Amorphous pharmaceutical solids: preparation, characterization and stabilization. Advanced Drug Delivery Reviews 2001, 48 (1), 27-42.

4. Gordon, M.; Taylor, J. S., Ideal copolymers and the second-order transitions of synthetic rubbers. i. non-crystalline copolymers. Journal of Applied Chemistry 1952, 2 (9), 493-500.

5. Arakawa, T.; Prestrelski, S. J.; Kenney, W. C.; Carpenter, J. F., Factors affecting short-term and long-term stabilities of proteins. Advanced drug delivery reviews 2001, 46 (1), 307-326.

6. Aizenberg, J.; Lambert, G.; Addadi, L.; Weiner, S., Stabilization of amorphous calcium carbonate by specialized macromolecules in biological and synthetic precipitates. Advanced Materials 1996, 8 (3), 222-226.

7. Raz, S.; Hamilton, P. C.; Wilt, F. H.; Weiner, S.; Addadi, L., The transient phase of amorphous calcium carbonate in sea urchin larval spicules: the involvement of proteins and magnesium ions in its formation and stabilization. Advanced Functional Materials 2003, 13 (6), 480-486.

8. Addadi, L.; Raz, S.; Weiner, S., Taking advantage of disorder: Amorphous calcium carbonate and its roles in biomineralization. Advanced Materials 2003, 15 (12), 959-970.

9. Raz, S.; Testeniere, O.; Hecker, A.; Weiner, S.; Luquet, G., Stable amorphous calcium carbonate is the main component of the calcium storage structures of the crustacean Orchestia cavimana. The Biological Bulletin 2002, 203 (3), 269-274.

10. Kerc, J.; Srcic, S., Thermal analysis of glassy pharmaceuticals. Thermochimica acta 1995, 248, 81-95.

11. Johnson, W., Bulk amorphous metal-An emerging engineering material. Jom 2002, 54 (3), 40-43.

12. Baitalow, F.; Wolf, G.; Schmidt, H.-G., Thermochemical Investigations of Calcium Carbonate Phase Transitions I. Thermal activated vaterite-calcite transition. Journal of thermal analysis and calorimetry 1998, 52 (1), 5-16.

13. Turnbull, A. G., A thermochemical study of vaterite. Geochimica et Cosmochimica Acta 1973, 37 (6), 1593-1601.

14. Wolf, G.; Günther, C., Thermophysical Investigations of the Polymorphous Phases of Calcium Carbonate. Journal of Thermal Analysis and Calorimetry 2001, 65 (3), 687-698.

15. Qi, C.; Zhu, Y.-J.; Lu, B.-Q.; Zhao, X.-Y.; Zhao, J.; Chen, F.; Wu, J., ATP-Stabilized Amorphous Calcium Carbonate Nanospheres and Their Application in Protein Adsorption. Small 2014, 10 (10), 2047-2056.

16. Qi, C.; Zhu, Y.-J.; Chen, F., Microwave Hydrothermal Transformation of Amorphous Calcium Carbonate Nanospheres and Application in Protein Adsorption. ACS Applied Materials \& Interfaces 2014, 6 (6), 4310-4320. 
17. Aizenberg, J.; Lambert, G.; Weiner, S.; Addadi, L., Factors involved in the formation of amorphous and crystalline calcium carbonate: A study of an ascidian skeleton. Journal of the American Chemical Society 2002, 124 (1), 32-39.

18. Aizenberg, J.; Weiner, S.; Addadi, L., Coexistence of amorphous and crystalline calcium carbonate in skeletal tissues. Connective tissue research 2003, 44 (1), 20-25.

19. Politi, Y.; Arad, T.; Klein, E.; Weiner, S.; Addadi, L., Sea urchin spine calcite forms via a transient amorphous calcium carbonate phase. Science 2004, 306 (5699), 1161-1164.

20. Grunenfelder, L. K.; Herrera, S.; Kisailus, D., Crustacean-Derived Biomimetic Components and Nanostructured Composites. Small 2014, 10 (16), 3207-3232.

21. Lakshminarayanan, R.; Loh, X. J.; Gayathri, S.; Sindhu, S.; Banerjee, Y.; Kini, R. M.; Valiyaveettil, S., Formation of Transient Amorphous Calcium Carbonate Precursor in Quail Eggshell Mineralization: An In Vitro Study. Biomacromolecules 2006, 7 (11), 3202-3209.

22. Termine, J. D.; Posner, A. S., Amorphous/crystalline interrelationships in bone mineral. Calc. Tis Res. 1967, 1 (1), 8-23.

23. Mahamid, J.; Sharir, A.; Addadi, L.; Weiner, S., Amorphous calcium phosphate is a major component of the forming fin bones of zebrafish: Indications for an amorphous precursor phase. Proceedings of the National Academy of Sciences 2008, 105 (35), 1274812753.

24. Bentov, S.; Weil, S.; Glazer, L.; Sagi, A.; Berman, A., Stabilization of amorphous calcium carbonate by phosphate rich organic matrix proteins and by single phosphoamino acids. Journal of Structural Biology 2010, 171 (2), 207-215.

25. Akiva-Tal, A.; Kababya, S.; Balazs, Y. S.; Glazer, L.; Berman, A.; Sagi, A.; Schmidt, A., In situ molecular NMR picture of bioavailable calcium stabilized as amorphous $\mathrm{CaCO} 3$ biomineral in crayfish gastroliths. Proceedings of the National Academy of Sciences 2011, 108 (36), 14763-14768.

26. Aizenberg, J.; Muller, D. A.; Grazul, J. L.; Hamann, D. R., Direct fabrication of large micropatterned single crystals. Science 2003, 299 (5610), 1205-1208.

27. Walsh, D.; Mann, S., Fabrication of hollow porous shells of calcium carbonate from self-organizing media. Nature 1995, 377 (6547), 320-323.

28. Pouget, E. M.; Bomans, P. H. H.; Goos, J. A. C. M.; Frederik, P. M.; De With, G.; Sommerdijk, N. A. J. M., The initial stages of template-controlled CaCO3 formation revealed by Cryo-TEM. Science 2009, 323 (5920), 1455-1458.

29. Politi, Y.; Metzler, R. A.; Abrecht, M.; Gilbert, B.; Wilt, F. H.; Sagi, I.; Addadi, L.; Weiner, S.; Gilbert, P., Transformation mechanism of amorphous calcium carbonate into calcite in the sea urchin larval spicule (Proceedings of the National Academy of Sciences of the United States of America (2008) 105, 45, (17362-17366) DOI:10.1073/pnas. 0806604105). Proceedings of the National Academy of Sciences of the United States of America 2008, 105 (50), 20045-20045.

30. Radha, A. V.; Forbes, T. Z.; Killian, C. E.; Gilbert, P. U. P. A.; Navrotsky, A., Transformation and crystallization energetics of synthetic and biogenic amorphous calcium carbonate. Proceedings of the National Academy of Sciences of the United States of America 2010, 107 (38), 16438-16443.

31. Bassett, D. C.; Marelli, B.; Nazhat, S. N.; Barralet, J. E., Stabilization of Amorphous Calcium Carbonate with Nanofibrillar Biopolymers. Advanced Functional Materials 2012, 22 (16), 3460-3469.

32. Arias, J. L.; Fernández, M. a. S., Polysaccharides and Proteoglycans in Calcium Carbonate-based Biomineralization. Chemical Reviews 2008, 108 (11), 4475-4482.

33. Turino, G. M.; Cantor, J. O., Hyaluronan in Respiratory Injury and Repair. American Journal of Respiratory and Critical Care Medicine 2003, 167 (9), 1169-1175.

34. Ros, M.; Casciaro, R.; Lucca, F.; Troiani, P.; Salonini, E.; Favilli, F.; Quattrucci, S.; Sher, D.; Assael, B. M., Hyaluronic Acid Improves the Tolerability of Hypertonic Saline in 
the Chronic Treatment of Cystic Fibrosis Patients: A Multicenter, Randomized, Controlled Clinical Trial. Journal of aerosol medicine and pulmonary drug delivery 2014, 27 (2), 133137.

35. Huang, P.-m.; Syrkina, O.; Yu, L.; Dedaj, R.; Zhao, H.; Shiedlin, A.; Liu, Y.-y.; Garg, H.; Quinn, D. A.; Hales, C. A., High MW hyaluronan inhibits smoke inhalation-induced lung injury and improves survival. Respirology 2010, 15 (7), 1131-1139.

36. Nenna, R.; Papoff, P.; Moretti, C.; De Angelis, D.; Battaglia, M.; Papasso, S.; Bernabucci, M.; Cangiano, G.; Petrarca, L.; Salvadei, S., Seven percent hypertonic saline$0.1 \%$ hyaluronic acid in infants with mild-to-moderate bronchiolitis. Pediatric pulmonology 2014, 49 (9), 919-925.

37. Monk, R.; Graves, M.; Williams, P.; Strange, C., Inhaled Alpha 1-Antitrypsin: Gauging Patient Interest in a New Treatment. COPD: Journal of Chronic Obstructive Pulmonary Disease 2013, 10 (4), 411-415.

38. Ridha, F. N.; Manovic, V.; Wu, Y.; Macchi, A.; Anthony, E. J., Post-combustion CO2 capture by formic acid-modified $\mathrm{CaO}$-based sorbents. International Journal of Greenhouse Gas Control 2013, 16 (0), 21-28.

39. Al-Hosney, H. A.; Carlos-Cuellar, S.; Baltrusaitis, J.; Grassian, V. H., Heterogeneous uptake and reactivity of formic acid on calcium carbonate particles: a Knudsen cell reactor, FTIR and SEM study. Physical Chemistry Chemical Physics 2005, 7 (20), 3587-3595.

40. Vagenas, N. V.; Gatsouli, A.; Kontoyannis, C. G., Quantitative analysis of synthetic calcium carbonate polymorphs using FT-IR spectroscopy. Talanta 2003, 59 (4), 831-836.

41. Meiron, O. E.; Bar-David, E.; Aflalo, E. D.; Shechter, A.; Stepensky, D.; Berman, A.; Sagi, A., Solubility and Bioavailability of Stabilized Amorphous Calcium Carbonate. Journal of Bone and Mineral Research 2011, 26 (2), 364-372.

42. Foran, E.; Weiner, S.; Fine, M., Biogenic Fish-gut Calcium Carbonate is a Stable Amorphous Phase in the Gilt-head Seabream, Sparus aurata. Sci. Rep. 2013, 3, 1-5.

43. Ihli, J.; Wong, W. C.; Noel, E. H.; Kim, Y.-Y.; Kulak, A. N.; Christenson, H. K.; Duer, M. J.; Meldrum, F. C., Dehydration and crystallization of amorphous calcium carbonate in solution and in air. Nature Communications 2014, 5, 1-10.

44. Leyva, A. G.; Polla, G.; de Perazzo, P. K.; Lanza, H.; de Benyacar, M. A. R., Thermal Decomposition of Copper (II) Calcium (II) Formate. Journal of Solid State Chemistry 1996, 123 (2), 291-295.

45. Wilson, R.; Elliott, J.; Dowker, S., Formate incorporation in the structure of Cadeficient apatite: Rietveld structure refinement. Journal of Solid State Chemistry 2003, 174 (1), 132-140.

46. Puri, V.; Dantuluri, A. K.; Kumar, M.; Karar, N.; Bansal, A. K., Wettability and surface chemistry of crystalline and amorphous forms of a poorly water soluble drug. European Journal of Pharmaceutical Sciences 2010, 40 (2), 84-93.

47. Bianco, S.; Tewes, F.; Tajber, L.; Caron, V.; Corrigan, O. I.; Healy, A. M., Bulk, surface properties and water uptake mechanisms of salt/acid amorphous composite systems. Int J Pharm 2013, 456 (1), 143-52.

48. Tewes, F.; Gobbo, O. L.; Amaro, M. I.; Tajber, L.; Corrigan, O. I.; Ehrhardt, C.; Healy, A. M., Evaluation of HP $\beta C D-P E G$ microparticles for salmon calcitonin administration via pulmonary delivery. Molecular Pharmaceutics 2011, 8 (5), 1887-1898.

49. Tewes, F.; Tajber, L.; Corrigan, O. I.; Ehrhardt, C.; Healy, A. M., Development and characterisation of soluble polymeric particles for pulmonary peptide delivery. Eur. J. Pharm. Sci. 2010, 41 (2), 337-352.

50. Matahwa, H.; Ramiah, V.; Sanderson, R. D., Calcium carbonate crystallization in the presence of modified polysaccharides and linear polymeric additives. Journal of Crystal Growth 2008, 310 (21), 4561-4569. 
51. Wang, C.; Zhao, X.; Zhao, J.; Liu, Y.; Sheng, Y.; Wang, Z., Biomimetic nucleation and growth of hydrophobic vaterite nanoparticles with oleic acid in a methanol solution. Applied Surface Science 2007, 253 (10), 4768-4772.

52. Saharay, M.; Yazaydin, A. O.; Kirkpatrick, R. J., Dehydration-induced amorphous phases of calcium carbonate. J Phys Chem B 2013, 117 (12), 3328-36.

53. Pitarresi, G.; Craparo, E. F.; Palumbo, F. S.; Carlisi, B.; Giammona, G., Composite Nanoparticles Based on Hyaluronic Acid Chemically Cross-Linked with $\alpha, \beta-$ Polyaspartylhydrazide. Biomacromolecules 2007, 8 (6), 1890-1898.

54. Healy, A. M.; Amaro, M. I.; Paluch, K. J.; Tajber, L., Dry powders for oral inhalation free of lactose carrier particles. Advanced Drug Delivery Reviews 2014.

55. Lee, Y.-H.; Sinko, P. J., Oral delivery of salmon calcitonin. Advanced Drug Delivery Reviews 2000, 42 (3), 225-238.

56. Vehring, R.; Foss, W. R.; Lechuga-Ballesteros, D., Particle formation in spray drying. Journal of Aerosol Science 2007, 38 (7), 728-746.

57. Ihli, J.; Kim, Y.-Y.; Noel, E. H.; Meldrum, F. C., The Effect of Additives on Amorphous Calcium Carbonate (ACC): Janus Behavior in Solution and the Solid State. Advanced Functional Materials 2013, 23 (12), 1575-1585.

58. Raiteri, P.; Gale, J. D., Water Is the Key to Nonclassical Nucleation of Amorphous Calcium Carbonate. Journal of the American Chemical Society 2010, 132 (49), 17623-17634.

59. Saharay, M.; James Kirkpatrick, R., Onset of Orientational Order in Amorphous Calcium Carbonate (ACC) upon Dehydration. Chemical Physics Letters 2014, 591 (0), 287291.

60. Rodriguez-Blanco, J. D.; Shaw, S.; Benning, L. G., The kinetics and mechanisms of amorphous calcium carbonate (ACC) crystallization to calcite, viavaterite. Nanoscale 2011, 3 (1), 265-271.

61. Ogino, T.; Suzuki, T.; Sawada, K., The formation and transformation mechanism of calcium carbonate in water. Geochimica et Cosmochimica Acta 1987, 51 (10), 2757-2767.

62. Ogino, T.; Suzuki, T.; Sawada, K., The rate and mechanism of polymorphic transformation of calcium carbonate in water. Journal of crystal growth 1990, 100 (1), 159167.

63. Sand, K.; Yang, M.; Makovicky, E.; Cooke, D. J.; Hassenkam, T.; Bechgaard, K.; Stipp, S., Binding of ethanol on calcite: the role of the $\mathrm{OH}$ bond and its relevance to biomineralization. Langmuir 2010, 26 (19), 15239-15247.

64. Ihli, J.; Kulak, A. N.; Meldrum, F. C., Freeze-drying yields stable and pure amorphous calcium carbonate (ACC). Chemical Communications 2013, 49 (30), 3134-3136.

65. Gebauer, D.; Gunawidjaja, P. N.; Ko, J.; Bacsik, Z.; Aziz, B.; Liu, L.; Hu, Y.; Bergström, L.; Tai, C. W.; Sham, T. K., Proto-Calcite and Proto-Vaterite in Amorphous Calcium Carbonates. Angewandte Chemie 2010, 122 (47), 9073-9075.

66. Pudipeddi, M.; Serajuddin, A., Trends in solubility of polymorphs. Journal of pharmaceutical sciences 2005, 94 (5), 929-939.

67. Butler, M. F.; Glaser, N.; Weaver, A. C.; Kirkland, M.; Heppenstall-Butler, M., Calcium Carbonate Crystallization in the Presence of Biopolymers. Crystal Growth \& Design 2006, 6 (3), 781-794.

68. Dickinson, S. R.; McGrath, K., Switching between kinetic and thermodynamic control: calcium carbonate growth in the presence of a simple alcohol. Journal of Materials Chemistry 2003, 13 (4), 928-933.

69. Dickinson, S. R.; Henderson, G. E.; McGrath, K. M., Controlling the kinetic versus thermodynamic crystallisation of calcium carbonate. Journal of crystal growth 2002, 244 (34), 369-378. 
70. Shekunov, B.; Chattopadhyay, P.; Tong, H. Y.; Chow, A. L., Particle Size Analysis in Pharmaceutics: Principles, Methods and Applications. Pharmaceutical Research 2007, 24 (2), 203-227.

71. DeCarlo, P. F.; Slowik, J. G.; Worsnop, D. R.; Davidovits, P.; Jimenez, J. L., Particle Morphology and Density Characterization by Combined Mobility and Aerodynamic Diameter Measurements. Part 1: Theory. Aerosol Science and Technology 2004, 38 (12), 1185-1205.

72. Tsapis, N.; Bennett, D.; Jackson, B.; Weitz, D. A.; Edwards, D. A., Trojan particles: Large porous carriers of nanoparticles for drug delivery. Proceedings of the National Academy of Sciences of the United States of America 2002, 99 (19), 12001-12005.

73. Tewes, F.; Paluch, K. J.; Tajber, L.; Gulati, K.; Kalantri, D.; Ehrhardt, C.; Healy, A. M., Steroid/mucokinetic hybrid nanoporous microparticles for pulmonary drug delivery. European Journal of Pharmaceutics and Biopharmaceutics 2013, 85 (3), 604-613.

74. Amaro, M. I.; Tajber, L.; Corrigan, O. I.; Healy, A. M., Optimisation of spray drying process conditions for sugar nanoporous microparticles (NPMPs) intended for inhalation. International journal of pharmaceutics 2011, 421 (1), 99-109.

75. Chan, H. K.; Clark, A. R.; Feeley, J. C.; Kuo, M. C.; Lehrman, S. R.; Pikal-Cleland, K.; Miller, D. P.; Vehring, R.; Lechuga-Ballesteros, D., Physical stability of salmon calcitonin spray-dried powders for inhalation. Journal of pharmaceutical sciences 2004, 93 (3), 792804.

76. Garcia-Verdugo, I.; Descamps, D.; Chignard, M.; Touqui, L.; Sallenave, J.-M., Lung protease/anti-protease network and modulation of mucus production and surfactant activity. Biochimie 2010, 92 (11), 1608-1617.

77. Youn, Y. S.; Kwon, M. J.; Na, D. H.; Chae, S. Y.; Lee, S.; Lee, K. C., Improved intrapulmonary delivery of site-specific PEGylated salmon calcitonin: Optimization by PEG size selection. J Control Release 2008, 125 (1), 68-75. 